cluded almond (Prunus dulcis), juniper (Juniperus spp.), laurustinus (Viburnum tinus) and photinia (Photinia $\times$ fraseri).

\section{Spray timing}

Timing ethephon sprays correctly is critical to eliminating the fruits. Flowering pears produce complete flowers that bloom over a period of 10 days to 2 weeks. To be effective on flowering pears, ethephon sprays must be applied early in the full bloom period, prior to fruit set; the sprays will not be effective later on, once the fruit begins to develop. Ethephon prevents fruit set, but does not eliminate flowers nor affect the duration of bloom in flowering pears. Complete spray coverage is also important, as flowers not contacted by the ethephon will successfully set fruit.

Determining when full bloom occurs for liquidambar is difficult, since the trees produce monoecious flowers that have no petals. Applying ethephon as new leaves begin to emerge has provided effective fruit elimination without damaging foliage.

\section{Special registration}

In 1990, the City of Modesto Parks Department applied for and was granted a California Special Local Needs Registration (24-C) allowing it to use ethephon on flowering pear for fruit elimination. Valid only within the City of Modesto, the registration enabled the department to treat numerous flowering pear street trees during 1990 and 1991. The level of fruit elimination was similar to that in our 1989 trial, but due to the high cost of maintaining the registration, the City of Modesto has since allowed it to expire.

Ethephon is not currently registered for eliminating the fruits of flowering pear and liquidambar. However, data from these and other trials are being used to justify an expanded ethephon label which would include these two species.

E. Perry is Farm Advisor, Stanislaus County. A. Lagarbo is Arborist, City of Modesto Parks Department.

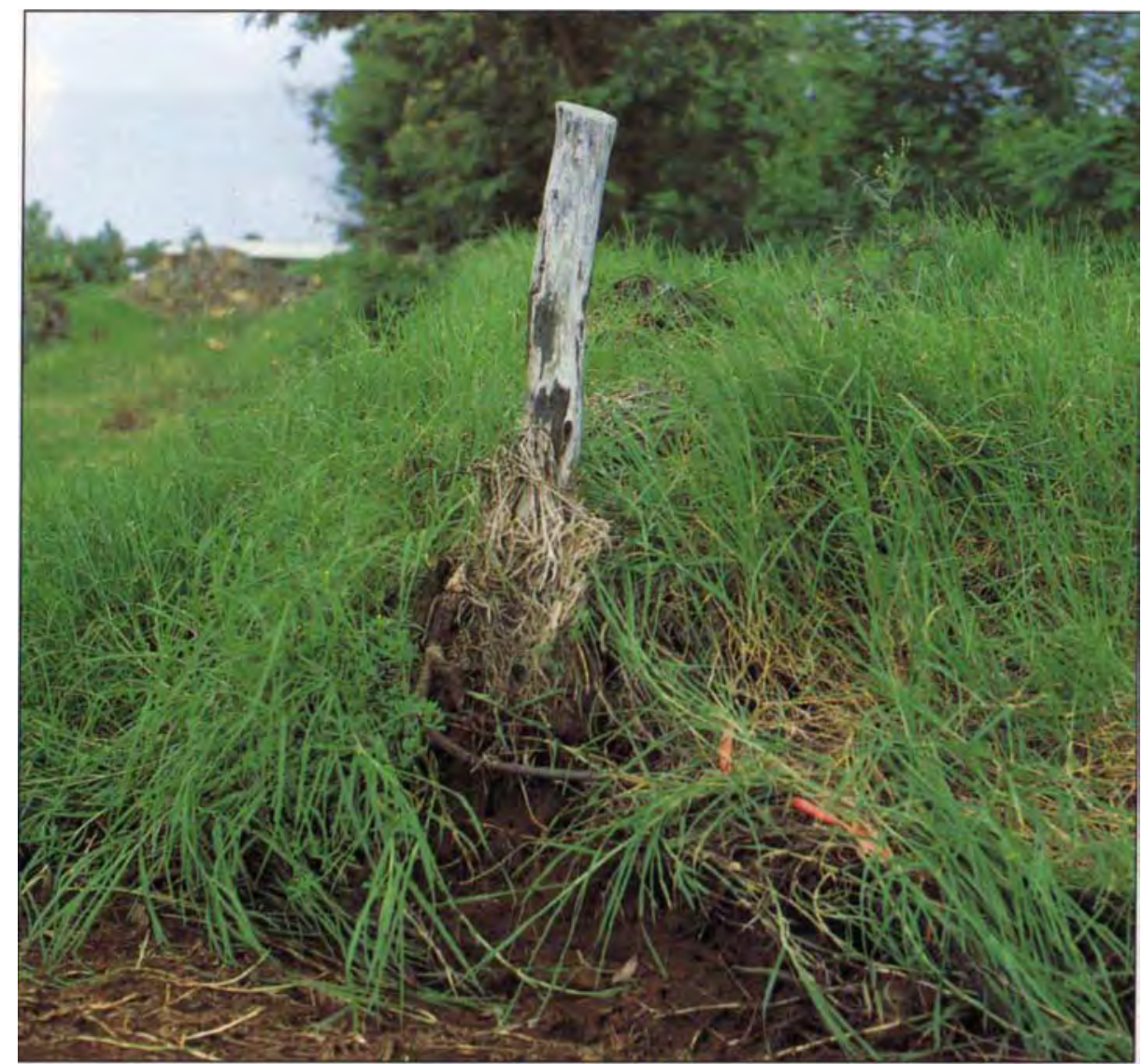

\title{
Herbicide program can control kikuyugrass in cool-season turf
}

\author{
David W. Cudney $\square$ James A. Downer $\square$ Victor A. Gibeault \\ J. Michael Henry a Clyde L. Elmore $\square$ John S. Reints
}

Kikuyugrass is an invasive perennial weed of turfgrass in California. Currently, complete renovation of infested turf is the most practical means of control, but this process can cost more than $\$ 1,500$ per acre and it removes the sward from use for up to 3 months. A less disruptive method uses multiple selective herbicide treatments with MSMA, triclopyr or a combination of MSMA plus triclopyr. This method inhibits the competitive ability of kikuyugrass while allowing the growth of desirable cool-season turf species.
Kikuyugrass (Pennisetum clandestinum Hochst. ex Chiov.) is an extremely aggressive perennial weed of turfgrass in California. A native African grass, it is well adapted to warm, temperate climates such as those of the coast and inland valleys of Southern and Central California. With its rapid stolon growth and thatch formation, it outcompetes desirable turfgrass species. Kikuyugrass reproduces both by seed and by stolons and rhizomes. It is unsuitable for most turf uses, including golf fairways, parks, and home lawns.

Currently there is no cultural or single, selective chemical means of 


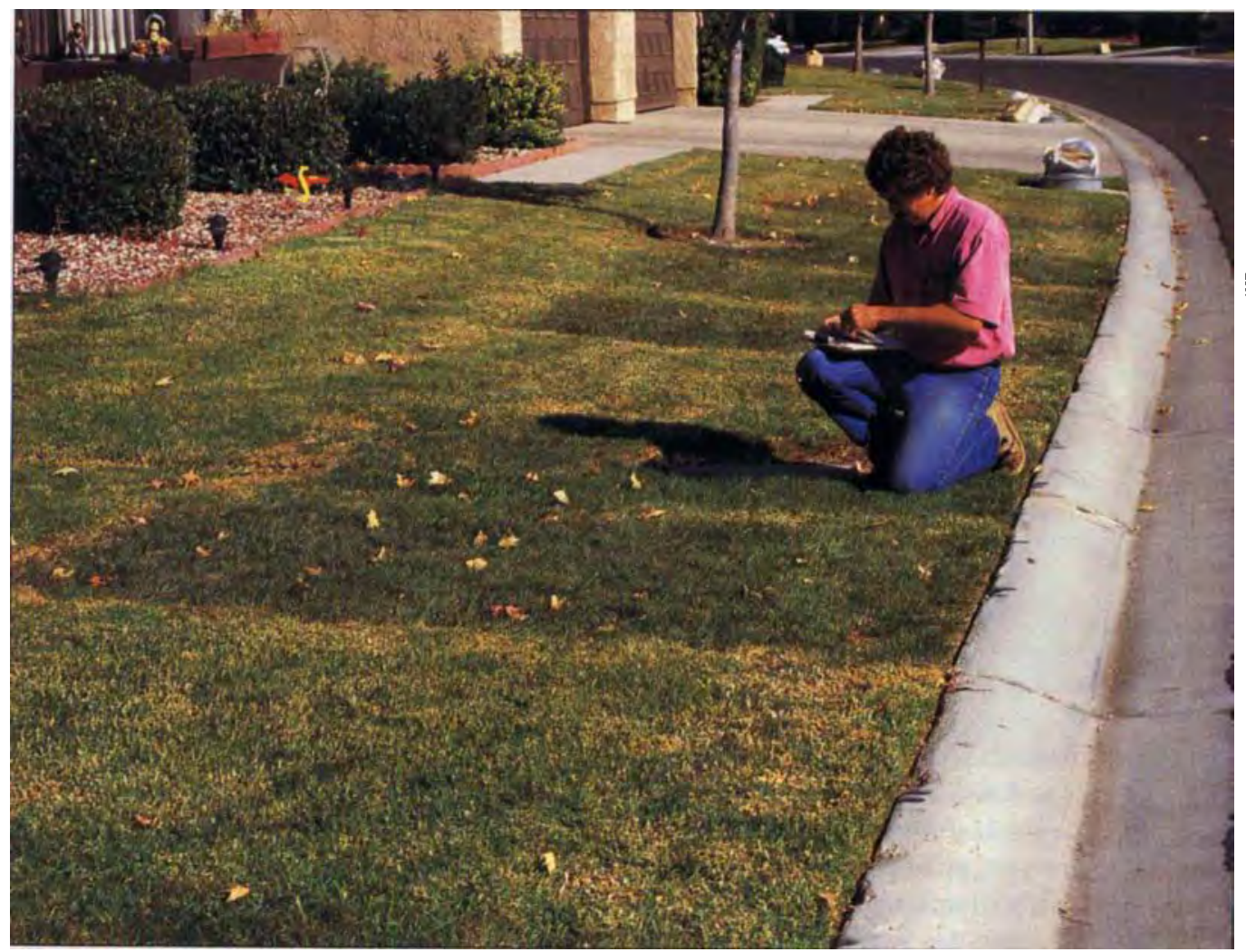

Far left, Kikuyugrass is an extremely aggressive perennial weed. Here it engulfs a barbedwire fence. (Photo by Clyde Elmore, Extension Weed Scientist, UC Davis)

Jim Downer, Farm Advisor, Ventura County, examines a field study in December 1991. The plot he is kneeling in had received four sequential treatments of triclopyr plus MSMA. Note the excellent stand of perennial ryegrass in comparison to the klkuyugrass in the untreated control plot in the foreground.

controlling kikuyugrass in existing turf. Commercially, complete renovation of the sward has been the solution of choice. Two methods have been used: The first involves treatment with glyphosate followed by thatch removal, reseeding with desirable turf species and treatment with preemergence herbicide to control emerging kikuyugrass seedlings. Siduron, the preemergence herbicide applied for this purpose in cool-season turf, is no longer registered for use in the United States. The second renovation method involves fumigation with methyl bromide followed by thatch removal and reseeding. This method too may not be available much longer. There is a strong movement to phase out the agricultural uses of methyl bromide by the year 2000 .

Renovation is expensive, often costing more than $\$ 1,500$ per acre. Both renovation methods result in loss of turf use for up to 3 months, the time it takes new desirable species to be reestablished. After renovation, the desired turf species are again subject to gradual reinvasion by kikuyugrass.
Postemergence herbicides may offer an effective alternative means of control. Other research supports this possibility. Multiple postemergence applications of MSMA have been reported to be effective in reducing kikuyugrass invasion. In a recent preliminary study, both MSMA and triclopyr were shown to injure kikuyugrass (Cudney, 1990, unpublished data). Sequential applications of postemergence herbicides that injure kikuyugrass but do not harm desirable cool-season turf species show promise of reducing the competitive ability of kikuyugrass so that the desirable species can be reestablished. Such sequential applications would have an added advantage of allowing a gradual conversion of kikuyugrass-infested swards back to desirable species and hence avoiding loss of turf use. Disruption would be minimal compared with the effects of fumigation and renovation.

\section{Experiment design}

Four field experiments were conducted in the coastal and inland valleys of Southern California from 1989 through 1991. These areas have a Mediterranean climate of mild winters and summers (the temperature rarely drops below $32^{\circ}$ or exceeds $100^{\circ} \mathrm{F}$ ). Each plot measured 5 feet by 10 feet. Plots were well maintained with adequate fertility and moisture and regular mowing to a height of approximately $1 \frac{1}{2}$ inches. Herbicides were applied in aqueous solutions with a $\mathrm{CO}_{2}$-pressurized backpack sprayer calibrated to deliver 30 gallons per acre of spray mixture at a pressure of $30 \mathrm{psi}$. The plots were not irrigated for 24 hours after each treatment. All treatments were arranged in randomized complete block designs and replicated four times. Data were subjected to an analysis of variance, and means were separated using Fisher's protected LSD at $P=0.05$.

\section{Kikuyugrass control trials}

The initial experiment took place in Ventura, California, beginning on August 1,1989 . The site had a mixed sward of perennial ryegrass (Lolium perenne L.) and Kentucky bluegrass (Poa pratensis L.) that had been in- 


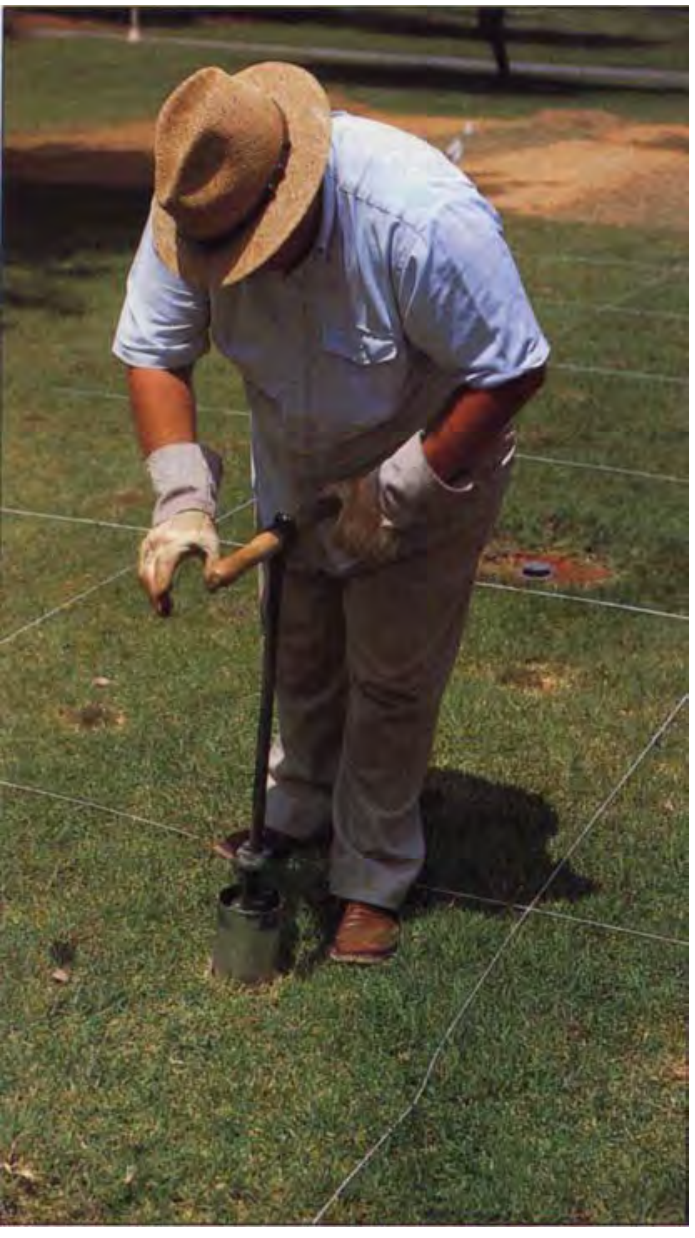

Steve Reints, technician at UC Riverside, pulls plugs from kikuyugrass sod for placement of cool-season turf plugs.

vaded by kikuyugrass. The weed was uniformly distributed; pretreatment estimates averaged $83 \%$ of the turf cover. The herbicide treatments consisted of MSMA at $2 \mathrm{lb}$ of active ingredient per acre (ai/ac), triclopyr at $1 / 2 \mathrm{lb}$ ai/ac and MSMA at $2 \mathrm{lb}$ ai/ac plus triclopyr at $1 / 2 \mathrm{lb}$ ai/ac, applied in a single treatment or in three sequential treatments made at 4- to 5-week intervals. Plots were evaluated on November 13,1989, 4 weeks after the last sequential treatment. The percentage of kikuyugrass control and phytotoxicity (injury and stand loss) to the Kentucky bluegrass/perennial ryegrass mix was estimated relative to the control plots in each replication.

Two additional trials were established in July 1991 in the coastal region of Southern California at Camarillo and Huntington Beach. Before treatment, both swards consisted of uniform mixes of approximately $85 \%$ kikuyugrass and $15 \%$ perennial ryegrass. The Huntington Beach site was mowed to a height of $1 / 2$ inch, raked and seeded with perennial ryegrass ('Manhattan $\mathrm{II}^{\prime}$ ) at 10 pounds per $1,000 \mathrm{ft}^{2}$ on July 5, 1991. Four weeks later, when the first herbicide treatments were made, the sward was approximately $75 \%$ kikuyugrass and $25 \%$ perennial ryegrass. The Camarillo site was also seeded at $10 \mathrm{lb}$ per 1,000 feet ${ }^{2}$ with 'Manhattan II' perennial $^{\prime}$ ryegrass, but seeding immediately followed the first herbicide treatments, which were made on July 6, 1991. The treatments at both locations consisted of MSMA (2 lb ai/ac), triclopyr ( $1 / 2 \mathrm{lb}$ $\mathrm{ai} / \mathrm{ac}$ ), or MSMA plus triclopyr (5 lb ai/ac MSMA + $1 / 2$ lb ai/ac triclopyr), made in four sequential applications at 4- to 5-week intervals. Three weeks after the last herbicide application, the percentage of perennial ryegrass cover was estimated, and the density of kikuyugrass was evaluated by counting rooted stems over 1 inch long $/ \mathrm{ft}^{2}$.

\section{Competition trials}

Over a 2-year period, a test was conducted at the UC Riverside Experiment Station to measure the differences in competitive ability of kikuyugrass and three cool-season turf cultivars. The cultivars were perennial ryegrass ('Manhattan II'), Kentucky bluegrass (an unknown blend) and tall fescue (Festuca arundinacea Schreb. 'Bonsai').

Stolons of kikuyugrass were pressed into a well-prepared seedbed in October 1989, and a uniform, vigorous kikuyugrass stand had formed by June 1990. Plugs 4 inches in diameter were then removed from well-established sods of the three turf species. Four plugs of each species were placed in separate 5-ft by 5-ft sections of the kikuyugrass sward. The experiment was a randomized complete block with two-factor, factorial treatments. The first factor was the turf species plugged and the second was herbicide treatment. After a 6-week establishment period, the plots received their first herbicide treatment. The treatments consisted of MSMA (2 lb ai/ac), triclopyr ( $1 / 2 \mathrm{lb} \mathrm{ai} / \mathrm{ac})$, or MSMA plus triclopyr (2 lb ai/ac MSMA + 1/2 lb ai/ac triclopyr), and an untreated control. Three treatments were made in 1990 , each at 6-week intervals (July 14, August 30 and October 16). In 1991, four applications were made at 6-week intervals (June 5, July 18, September 2 and October 15). On November 17, 1991, at the end of the second year, plots were evaluated for growth of the turf cultivars (based on the diameter of the plugs of the three turf species) and kikuyugrass density (the number of rooted stems with lengths of at least $1 \mathrm{inch} / \mathrm{ft}^{2}$ ).

\section{Kikuyugrass control results}

At the Ventura site, all three treatments - MSMA, triclopyr and MSMA plus triclopyr — injured kikuyugrass initially as single applications, but resulted in little control by the end of the test (fig. 1). However, sequential applications of these treatments improved control. MSMA and triclopyr applied sequentially were similar in their percentage control (52\% and 50\% respectively). Sequential applications of MSMA plus triclopyr together gave the best control by the end of the test $(88 \%)$. The Kentucky bluegrass/perennial ryegrass mix sustained no injury from any of the treatments except for slight discoloration and stunting, which lasted less than 1 week after each application (data not shown). The desired species had filled in the areas vacated by kikuyugrass and were

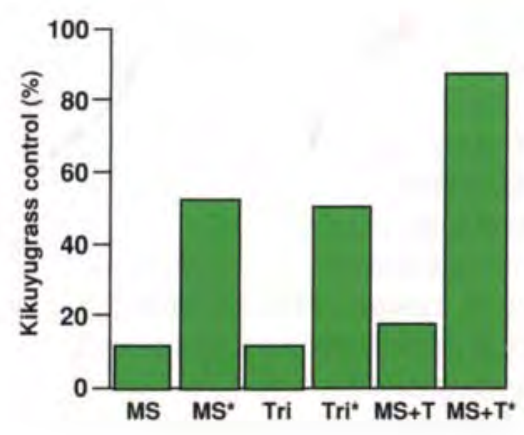

Fig. 1. Effects of herbicide treatments on percentage kikuyugrass control at Ventura, California (November 13,1989). * indicates sequential treatments. MS = MSMA, Tri $=$ triclopyr, and $M S+T=$ MSMA plus triclopyr. LSD with $p=0.05$ is $8 \%$. 


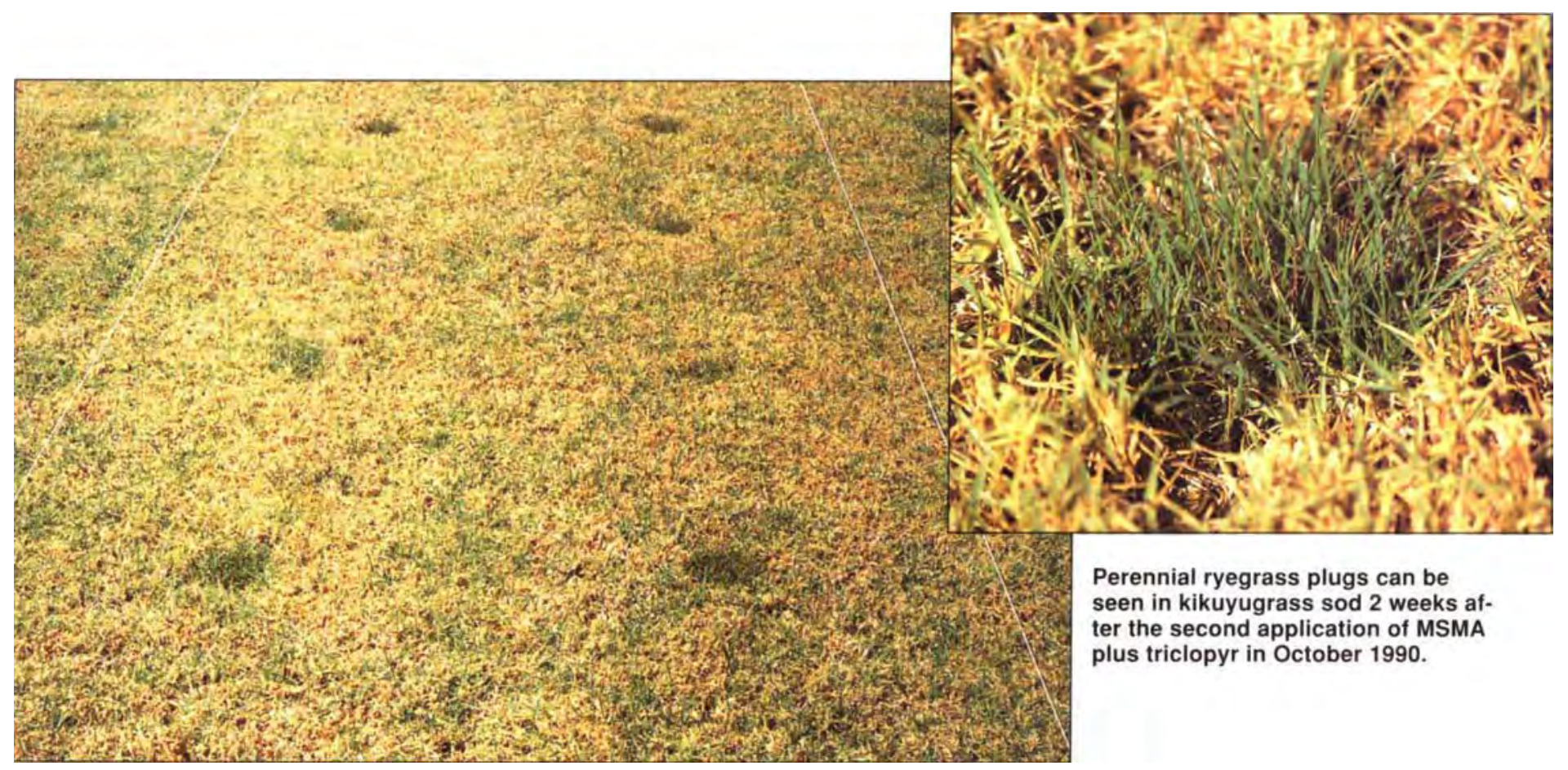

dominant in the plots that had received the sequential MSMA plus triclopyr treatments.

In the 1991 trials at Huntington Beach and Camarillo, sequential herbicide treatments controlled kikuyugrass and increased the percentage of perennial ryegrass at both sites (figs. 2 and 3). Triclopyr reduced kikuyugrass density to 1.4 and 3.6 1-inch stems $/ \mathrm{ft}^{2}$ for Huntington Beach and Camarillo, respectively. MSMA reduced kikuyugrass density to 5.8 and 26.41 -inch stems $/ \mathrm{ft}^{2}$ for Huntington Beach and Camarillo, respectively. MSMA plus triclopyr reduced kikuyugrass density to 0 for both Huntington Beach and

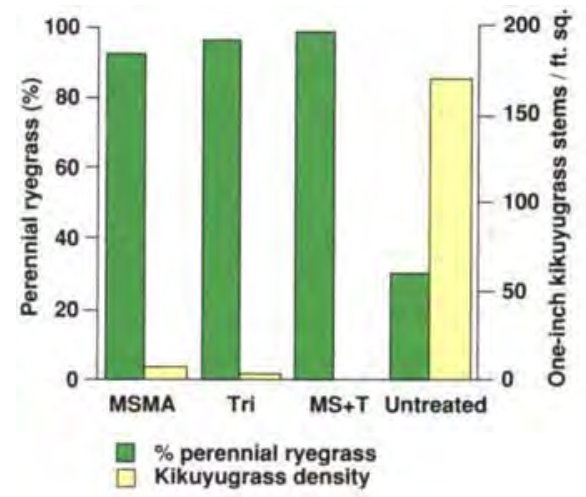

Fig. 2. Effects of sequential herbicide treatments on establishment of perennial ryegrass and kikuyugrass density at the end of the 1991 growing season in Huntington Beach. LSD with $p=0.05$ is $14 \%$ for percentage of perennial ryegrass and 34 stems/foot $^{2}$ for kikuyugrass density.
Camarillo. By comparison, the kikuyugrass density in the untreated plots was 170.8 and 140.11 -inch stems $/ \mathrm{ft}^{2}$ for the two sites.

The percentage of perennial ryegrass increased as the density of kikuyugrass declined. With sequential applications of triclopyr, perennial ryegrass varied from $95.8 \%$ to $85 \%$ for Huntington Beach and Camarillo, respectively; with MSMA it varied from $92.3 \%$ to $66.2 \%$ for the two sites.

Where kikuyugrass was more completely controlled by the MSMA plus triclopyr treatment, the percentage of perennial ryegrass varied from $98 \%$ to $100 \%$.

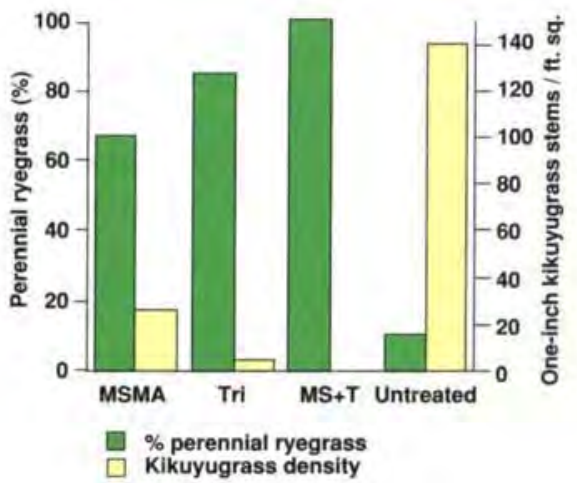

Fig. 3. Effects of sequential herbicide treatments on establishment of perennial ryegrass and kikuyugrass density at the end of the 1991 growing season in Camarillo. LSD with $p=0.05$ is $22 \%$ for percentage of perennial ryegrass and 39 stems/foot ${ }^{2}$ for kikuyugrass density.

\section{Competition results}

Of the three cultivars, tall fescue had the greatest overall mean plug diameter (5.7 inches) at the end of the second growing season (fig. 4). Perennial ryegrass and Kentucky bluegrass had overall mean plug diameters of 4.7 and 4.9 inches, respectively. Competition from the kikuyugrass sod had reduced the plug diameter in untreated control plots relative to the treated plots $(3,2.8$ and 2.5 inches for tall fescue, perennial ryegrass and Kentucky bluegrass control plots, respectively).

Sequential herbicide application of MSMA, triclopyr or MSMA plus

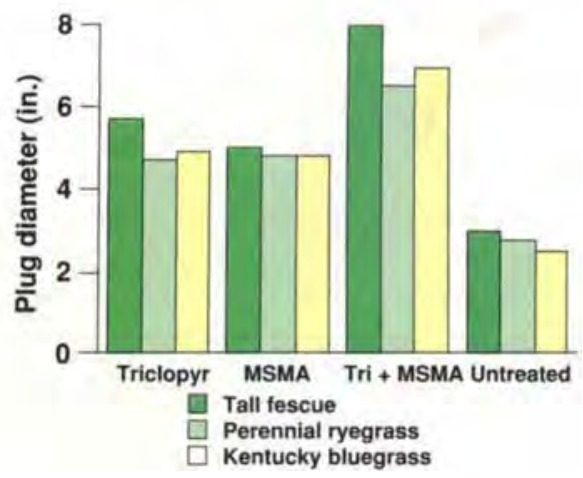

Fig. 4. Diameter of three turfgrass cultivars affected by herbicide treatments and kikuyugrass competition at Riverside, California, in 1991 at the end of the second year. LSD with $p=\mathbf{0 . 0 5}$ for all interactions among cultivars and herbicide treatments is $\mathbf{1 . 5}$ inches. 
triclopyr resulted in reduced kikuyugrass competition and increased plug growth in all turf cultivars (fig. 4).

Kikuyugrass density at the end of the experiment was reduced most by sequential treatments of MSMA plus triclopyr (7.3 stems $/ \mathrm{ft}^{2}$ compared with $203.5 \mathrm{stems} / \mathrm{ft}^{2}$ in the control plots).

Sequential treatments of MSMA and triclopyr reduced kikuyugrass density to 54.4 and 39.0 stems $/ \mathrm{ft}^{2}$, respectively.

\section{Management program}

The results of this research can be integrated into a kikuyugrass management program. Where cool-season species such as perennial ryegrass, tall fescue and Kentucky bluegrass are in a mixed sward with kikuyugrass, sequential applications of a combination of MSMA and triclopyr will reduce the density and competitiveness of the kikuyugrass, allowing the desired cool-season species to reestablish themselves. Some reseeding of the cool-season species may be necessary during the reestablishment process if the initial cool-season stand is not adequate or uniform. Once the desired species takes hold again, proper management to keep it competitive, including an occasional herbicide treatment as needed, should prevent kikuyugrass reinvasion.

The manufacturer of triclopyr has altered labeling information to include multiple applications of triclopyr and triclopyr plus MSMA for kikuyugrass control in cool-season turf.

D. W. Cudney, V. A. Gibeault and J.S. Reints are Extension Weed Specialist, Environmental Horticulture Specialist, and Staff Research Associate, respectively, in the Department of Botany and Plant Sciences, UC Riverside; J. A. Downer and J. $M$. Henry are Farm Advisors in Ventura and Orange counties, respectively. C. $L$. Elmore is Extension Weed Specialist, UC Davis.

This research and continuing research with kikuyugrass control involving additional herbicides and turf species is being supported by The Northern and Southern California Golf Associations.

\title{
Tomatoes respond to simple drip irrigation schedule and moderate nitrogen inputs
}

\author{
Timothy K. Hartz $\square$ Michelle LeStrange $\square$ Donald M. May
}

\begin{abstract}
Scheduling drip irrigation of fresh market tomatoes according to CIMIS ETo data and plant canopy development has proved simple and efficient. Using an easy calculation, maximum yields were produced in both a mild coastal climate and the San Joaquin Valley. In similar trials, researchers confirmed that drip-irrigated tomato crops need only modest levels of nitrogen fertigation and successfully tested a new, portable device that will enable growers to measure petiole nitrogen without leaving the farm.
\end{abstract}

The fresh market tomato industry in recent years has experienced a drip irrigation revolution. In the mid-1980s, less than $20 \%$ of California's acreage was drip irrigated; today, the majority of growers of fresh market tomatoes have made the switch. This rapid change has been driven in part by a concern over water availability, but mainly by the advances in drip irrigation technology, which have reduced costs (relative to other production inputs), improved system performance and manageability, and dramatically improved yields.

Now the challenge for fresh market tomato growers is to manage drip irrigation for high crop productivity while maximizing the efficiency of irrigation and nitrogen fertigation. Finding the most appropriate drip irrigation and nitrogen schedules was the goal of the studies we conducted from 1990 to 1992 at the UC South Coast Field Station (SCFS) in Irvine and the West Side Field Station (WSFS) near Five Points.

\section{Scheduling irrigation}

A 2-year trial at SCFS examined three methods of scheduling irrigation: Two treatments were based on estimates of evapotranspiration (the loss of water through evaporation from the soil surface and plant transpiration, abbreviated here as ETo) generated by the California Irrigation Management and Information System (CIMIS) computerized weather network. In one of them, ETo values were modified for crop growth stage by multiplying by predetermined crop coefficients (fig. 1) adapted from those in the UC Cooperative Extension Leaflet 21427, which were developed by compiling information from many tomato irrigation studies. In the other treatment, CIMIS ETo was modified for crop growth stage by multiplying by the estimated percentage of the soil surface covered by foliage; foliage cover was estimated by measuring the average plant canopy spread (in inches) and dividing by the bed width (60 inches).

The advantage of using a crop canopy coverage percentage instead of

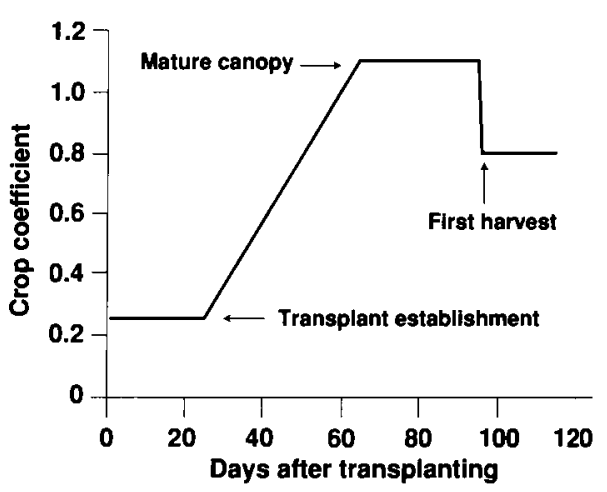

Fig. 1. UC Cooperative Extension crop coefficients used in the drip irrigation scheduling trial at SCFS. 